\title{
Insulin-like growth factors and body growth in chickens divergently selected for high or low growth rate
}

\author{
C Beccavin, B Chevalier, L A Cogburn ${ }^{1}$, J Simon and M J Duclos \\ Institut National de la Recherche Agronomique, Centre de Recherche de Tours, Station de Recherches Avicoles, 37380 Nouzilly, France \\ ${ }^{1}$ University of Delaware, Department of Animal and Food Sciences, Newark, Delaware 19717, USA \\ (Requests for offprints should be addressed to M J Duclos; Email: duclos@tours.inra.fr)
}

\begin{abstract}
Insulin-like growth factors (IGFs) stimulate growth rate in a number of animal species and are likely to contribute to genetic variations of growth potential. The present study was designed to link levels of IGF-I and IGF-II mRNA and peptides with growth rate in divergently selected genotypes of chickens with high (HG) or low (LG) growth rates. Circulating IGF-I and -II and hepatic mRNA levels were measured under ad libitum feeding conditions from 1 to 12 weeks of age, and at 6 weeks of age under three different nutritional conditions (fed, fasted for 16 or $48 \mathrm{~h}$, re-fed for 4 or $24 \mathrm{~h}$ after a 48 -h fast). IGF binding proteins (IGFBPs) were also measured. Circulating IGFs increased with age and were higher in HG chickens from 1 to 6 weeks. They decreased with fasting and only IGF-II was fully restored after $24 \mathrm{~h}$ of re-feeding, while IGF-I remained low. A significant decrease in steady state IGF-I
\end{abstract}

mRNA levels was also observed with fasting. Across the nutritional study, hepatic IGF-I mRNAs were significantly higher in HG chickens. Variations of IGF-II mRNA levels with nutritional state or genotype exhibited a similar trend. IGFBP (28, 34 and $40 \mathrm{kDa})$ levels increased with age, while only faint differences were observed between genotypes. IGFBP-28 transiently increased with fasting and was inversely related to blood glucose and insulin levels, suggesting that it is equivalent to mammalian IGFBP-1. In HG chickens, IGFBP-28 and IGFBP-34 levels decreased markedly following refeeding. Therefore, high and low growth rates were respectively associated with high and low IGF-I and -II levels, supporting the hypothesis of a stimulatory role for both IGFs during post-hatching growth of chickens.

Journal of Endocrinology (2001) 168, 297-306

\section{Introduction}

Genetic models exhibiting extreme (high or low) growth potential are valuable tools for studying the regulatory roles of hormones and growth factors. Alterations in the concentrations of circulating growth hormone $(\mathrm{GH})$, the central player in the somatotroph axis, have explained a number of genetic variations of growth in the mouse (Efstratiadis 1998). Surprisingly, higher GH levels in chickens are consistently associated with low growth rates, whether in unrelated genotypes (such as broiler vs layer) (Harvey et al. 1979, Burke \& Marks 1982, Goddard et al. 1988) or in divergently selected genotypes (Nir et al. 1987). This suggests that GH levels do not directly explain growth rate in the chicken and implies the need for studies on the factors acting downstream of $\mathrm{GH}$, namely the insulin-like growth factors (IGFs). The physiology of the IGF system in birds has been described in recent reviews (McMurtry et al. 1997, Duclos et al. 1999).

The possible involvement of the IGF system in explaining differences between chickens divergently selected for high (HG) or low (LG) growth rates has already been considered. On the one hand, adult myoblasts isolated from HG chicks were more responsive to serum and IGF-I than those from LG chicks (Duclos et al. 1996). The pathways accounting for this remains to be determined. On the other hand, no difference was found in either the number, the affinity or the tyrosine kinase activity of solubilized and purified IGF-I receptors from muscles of HG and LG chickens at 1 or 7 weeks of age (Oudin et al. 1998). Data on circulating IGF-I, IGF-II and IGFBPs, and their corresponding mRNAs are missing for a full interpretation of the involvement of the IGF system. The objective of the present study was to assess those parameters in HG and LG chickens during the early period of post-hatch growth (1-12 weeks of age). Responses to extreme nutritional states (ad libitum feeding, prolonged fasting and re-feeding), which in mammals largely alter the concentrations of circulating IGF peptides and IGFBPs, were also compared. The IGF system (mainly IGF-I) is significantly altered by genotype, suggesting a key role in the control of growth rate in broiler chickens. 


\section{Materials and Methods}

\section{Animals}

These studies were performed at the Institut National de la Recherche Agronomique, Research Center of Nouzilly, France using experimental strains of chickens. All animal procedures and care were performed in accordance with Authorization 006621 issued by the French Ministry of Agriculture and Fishery to M J Duclos. Male chickens were from the 37th and the 38th generation of high (HG) and low (LG) growth rate lines which have been divergently selected for high or low body weights at 9 weeks of age (Ricard 1975). In the first experiment, chickens from the 37 th generation were raised in floor pens and given free access to a regular and balanced diet under $14 \mathrm{~h}$ light : $10 \mathrm{~h}$ darkness cycles. Blood samples were obtained at 1 and 6 weeks of age; after clotting at room temperature and centrifugation, sera were collected, aliquoted and stored at $-20{ }^{\circ} \mathrm{C}$. After sacrifice, livers were collected, frozen, ground in liquid nitrogen using a mortar and pestle and kept at $-80{ }^{\circ} \mathrm{C}(n=8$ per age and genotype). For the longitudinal study of the second experiment, birds from the 38th generation were raised on the floor under the same conditions, serum samples were obtained at $1,2,4,6$ and 12 weeks of age $(n=8$ per age and genotype). In order to examine the effect of the nutritional status, birds of the same flock were raised in cages and fed ad libitum until 6 weeks of age when they were submitted to one of the following regimens: ad libitum feeding, fasting for 16 or $48 \mathrm{~h}$ or ad libitum re-feeding for 4 or $24 \mathrm{~h}$ after a $48 \mathrm{~h}$ fast $(n=8$ chickens per nutritional state and genotype). Blood samples were collected and chilled on ice using heparin as anticoagulant. After centrifugation, plasma were collected, aliquoted and stored at $-20{ }^{\circ} \mathrm{C}$. After sacrifice, livers were collected and treated as above.

\section{IGF-I and -II RIA}

Recombinant DNA-derived human IGF-I (hIGF-I) and hIGF-II were kindly provided by Ciba-Geigy (Basle, Switzerland), recombinant chicken IGF-I and IGF-II (cIGF-I and cIGF-II) were obtained from GroPep Pty Ltd (Adelaide, Australia). Human IGF-I and hIGF-II were iodinated as described previously (Duclos et al. 1994). IGFs were extracted from serum or plasma following acidification and ultrafiltration using Centricon 30 membranes (Amicon, Millipore Corp., Saint-Quentin en Yvelines, France), and assayed by heterologous RIAs as validated previously (Beccavin et al. 1999). Samples from experiment 1 or experiment 2 , longitudinal and nutritional study, were assayed independently in three different assays and processed as one dilution in triplicate or two different dilutions in duplicate depending upon age and nutritional state.

\section{Determination of glucose and insulin circulating concentrations}

Plasma concentrations of glucose and insulin were measured only in the nutritional study (experiment 2). Plasma glucose levels were determined using an automated analyser (Glucose Beckman Analyser 2, Palo Alto, CA, USA). Plasma insulin concentrations were measured by RIA using a guinea pig anti-porcine insulin serum $(\mathrm{Ab}$ 27-6, provided by Dr G Rosselin, Hôpital Saint-Antoine, Paris, France) using iodinated porcine insulin as a tracer and chicken insulin (Litron Laboratories, Rochester, NY, USA) as a standard, as previously described (Simon et al. 1974). All samples were processed in one assay at one dilution in triplicate or at two or three different dilutions in duplicate, depending on the nutritional state.

\section{IGFBP analysis}

Serum or plasma samples were subjected to SDS polyacrylamide gel electrophoresis and Western ligand blotting (WLB) using ${ }^{125}$ I-hIGF-I as previously described (Beccavin et al. 1999). Each experimental parameter (age, genotype or nutritional state) was tested within a single experiment running two gels in parallel and splitting individual samples from each experimental group (6 or 8) in half on each gel. Following transfer, the two membranes were incubated with the same batch of ${ }^{125}$ I-hIGF-I. Quantifications were performed using a Phosphorimager (Storm 840, Molecular Dynamics, Bondoufle, France).

\section{$R N A$ isolation and analysis}

Total RNA was extracted from liver (Chomczynski \& Sacchi 1987) using a commercial kit (RNA Instapure, obtained from Eurogentec France s.a., Angers, France) and their integrity was checked by denaturing agarose gel electrophoresis (not shown). The cIGF-I cDNA (224 bp) and chicken IGF type 1 receptor (cIGFR) cDNA (274 bp) were previously described (Armstrong \& Hogg 1992, 1996). The cIGF-II cDNA (406 bp) obtained from Dr M Holzenberger and Dr C Ayer-LeLievre (Institut d'Embryologie, Nogent sur Marne, France) corresponded to $n t-20$ to +386 of the published cIGF-II sequence (Darling \& Brickell 1996) cloned in the sense orientation into pGEM-4Z (Promega, Charbonnières, France) between the EcoRI and SacI restriction sites. A cDNA fragment including $170 \mathrm{bp}$ of the chicken 18S cDNA (nt +54 to +223$)$ and 53 bp of plasmid vector was amplified by PCR (5'-GTGCGATCGGCTCGAGGTT-3'; 5'-GCCGCTCGAGCATGCATCTAGA-3') from a c18S cDNA cloned in antisense position (obtained from Dr A L Johnson, University of Notre Dame, Notre Dame, IN, USA; Johnson et al. 1998). A T7 promoter was subsequently added by PCR as described in RPA III instruction manual (Ambion, Clinisciences, Montrouge, France). An 
extended forward primer including a core $\mathrm{T} 7$ sequence was used (5'-TAATACGACTCACTATAG GGTGC GATCGGCTCGAGGTTA-3'). Labelled antisense riboprobes were prepared from the linearized cDNA clones or the PCR c18S product using $\left[{ }^{32} \mathrm{P}\right] \mathrm{CTP}$ (ICN Pharmaceuticals France, Orsay, France) and a Riboprobe Combination System (Promega, Charbonnières, France). About $2 \times 10^{8}$ (IGF-I, IGF-II and IGFR) or $2 \times 10^{5}(18 \mathrm{~S})$ d.p.m. of labelled RNA probes were obtained from $1 \mu \mathrm{g}$ of cDNA. These were used to quantify mRNA levels by ribonuclease protection assay using the RPA III kit (Ambion, Clinisciences, Montrouge, France). Two RPA experiments were run in parallel. In one, the RNA extract $(20 \mu \mathrm{g})$ was hybridized with a mixture of labelled antisense RNA corresponding to IGF-II, IGFR (200 000 d.p.m.) and c18S (2000 d.p.m.). In the other it was hybridized with 200000 d.p.m. of the labelled antisense RNA corresponding to IGF-I alone. Following RNAse digestion, the protected hybrids were submitted to electrophoresis on an $8 \%$ polyacrylamide/8 $\mathrm{M}$ urea denaturing gel which was subsequently dried before exposure to phosphor screen imager or autoradiography. Quantification of protected fragments was performed using a Phosphorimager (Storm 840, Molecular Dynamics, Bondoufle, France). To account for possible inter-sample variability and to normalize data, the radioactivity of each band was expressed as a ratio of the band corresponding to c18S rRNA. However, variability in specific activities of the different probes does not permit comparisons between different experiments.

\section{Statistical analysis}

All results were presented as the mean ( \pm s.E.M.) and analysed by one- or two-way ANOVA as appropriate, followed by least square mean comparisons (LSM) between means using the SuperAnova Software (Abacus Concepts, Inc., Berkeley, CA, USA).

\section{Results}

\section{Growth and blood parameters in the longitudinal studies}

The growth curves of HG and LG chickens of the 38th generation between 1 and 12 weeks of age are shown in Fig. 1. Body weights recorded at 1 and 6 weeks of age in the 37th generation are also indicated by bars. Growth performance was largely different between the two genotypes and fairly stable from generation to generation.

Circulating concentrations of IGF-I and IGF-II in animals from the 38th and the 37th generation are shown in Fig. 2A and B respectively. IGF-I gradually increased from 1 to 6 weeks of age in HG chickens and from 1 to 12 weeks in LG chickens (Fig. 2A). Across the 1-6 weeks period the concentrations were consistently $(P<0 \cdot 001$ at

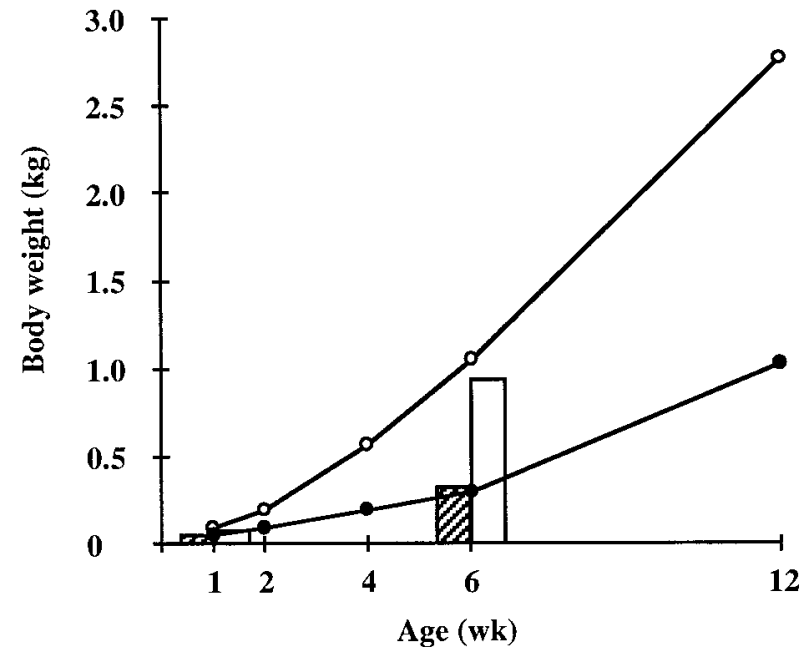

Figure 1 Body weight of HG and LG chickens. At the 37th generation, birds were weighed at 1 and 6 weeks only; these results are shown as bars. Data are means \pm S.E.M.S (37th generation: $\mathrm{HG}$, open bars and LG, hatched bars; 38th generation:

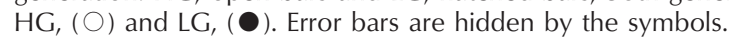

each age) higher in HG chickens than in LG chickens. An increase in circulating IGF-II concentrations with age was also observed across lines (Fig. 2A), averages at 6 weeks of age were significantly higher than at 1 week of age $(P<0 \cdot 01$, Fig. 2). During the $1-6$ weeks of age period, IGF-II concentrations were higher $(P<0 \cdot 01)$ in HG chickens at 2,4 and 6 weeks of age $(P<0 \cdot 05)$. At 12 weeks of age, IGF-I and IGF-II concentrations were very similar between the two lines. At 1 and 6 weeks of age, birds from the 37th generation (Fig. 2B) were qualitatively close, with similar differences observed between genotypes across age. However, in birds from this earlier generation, the differences for IGF-I and IGF-II concentrations between the two genotypes were only significant at 6 weeks of age.

A typical WLB using chicken serum samples from both genotypes at 1 and 6 weeks of age is shown in Fig. 3 . Three major IGF binding proteins, designated as IGFBP$28,-34$ and -40 according to their molecular weights, were identified (Beccavin et al. 1999). Their radiolabelling obviously increased with age, which was further substantiated in a larger number of individual chickens from the 37th and the 38th generation (data not shown). The effect of genotype was then considered independently, in all available samples age by age. IGFBP-34 labelling was higher $(P<0 \cdot 01)$ in HG than in LG chickens at 6 weeks of age only, in both generations $(35 \pm 11 \%$ and $77 \pm 19 \%$ increases respectively).

\section{Effect of the nutritional state on blood parameters}

Circulating glucose and insulin concentrations were measured as indicators of the metabolic status. Indeed, 
A

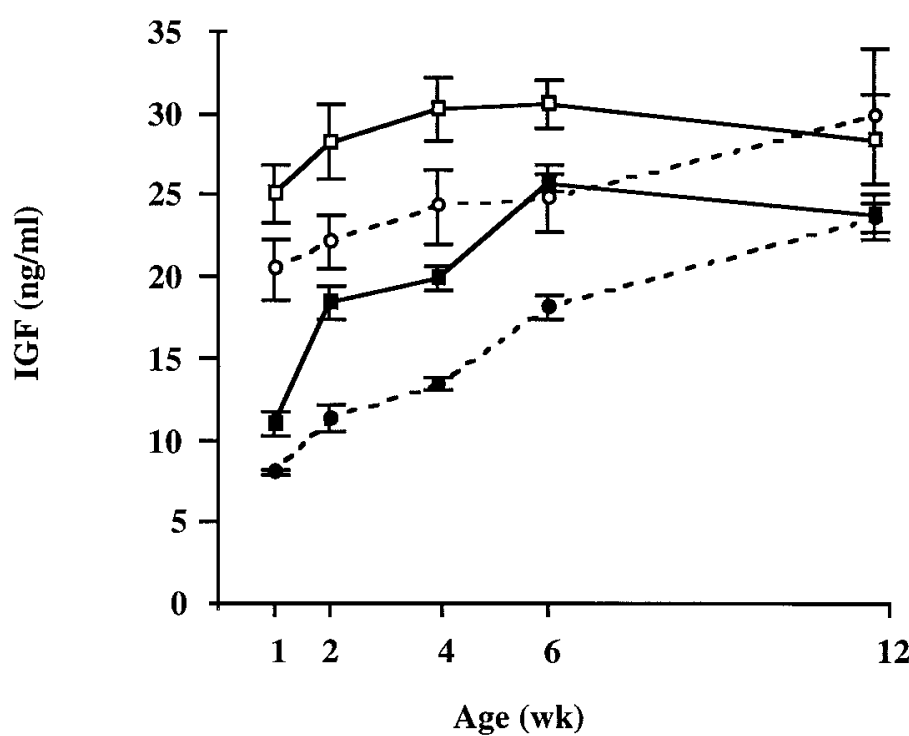

B

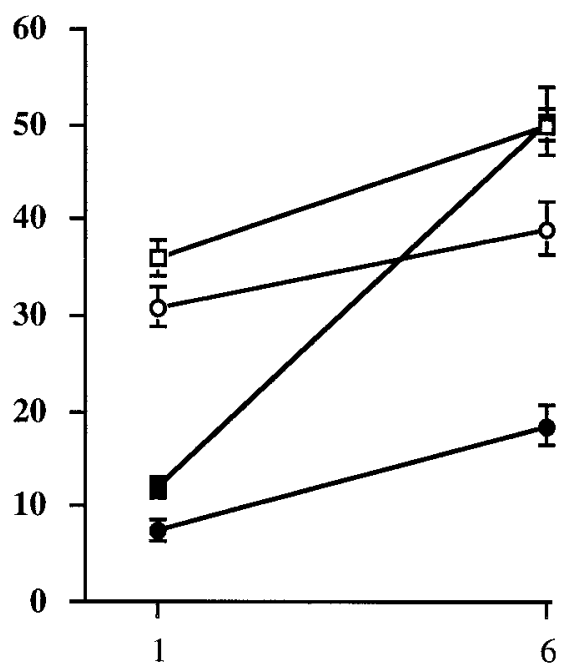

Age (wk)

Figure 2 Effects of age and genotype on circulating IGF-I (closed symbols) and IGF-II (open symbols) concentrations at the 38th (A) or 37 th generation (B). Individual serum samples ( $n=8$ in each category) were collected from HG (squares) and LG (circles) chickens between 1 and 12 weeks of age. Circulating IGF-I and IGF-II levels were measured by RIA. IGF-I and IGF-II values correspond to means \pm S.E.M.S. The statistical analysis of these data is presented in the Results section.

both parameters (Fig. 4) were significantly altered by nutritional state $(P<0 \cdot 001)$. Insulin levels, but not glucose, were also altered by the genotype $(P<0 \cdot 001)$. No significant interaction was found between genotype and nutritional status for either parameter, suggesting that both genotypes responded similarly to feed intake. Glucose and insulin levels decreased after $16 \mathrm{~h}$ fasting, as expected from earlier studies (Simon \& Leclercq 1982), and both returned to near normal after $48 \mathrm{~h}$ fasting. Re-feeding chickens for $4 \mathrm{~h}$ after a $48 \mathrm{~h}$ fast increased glucose and insulin levels over those observed after $48 \mathrm{~h}$. After $24 \mathrm{~h}$ re-feeding, both glucose and insulin returned to levels similar to those of fed animals in both lines. For insulin, the difference between genotypes mainly resulted from the

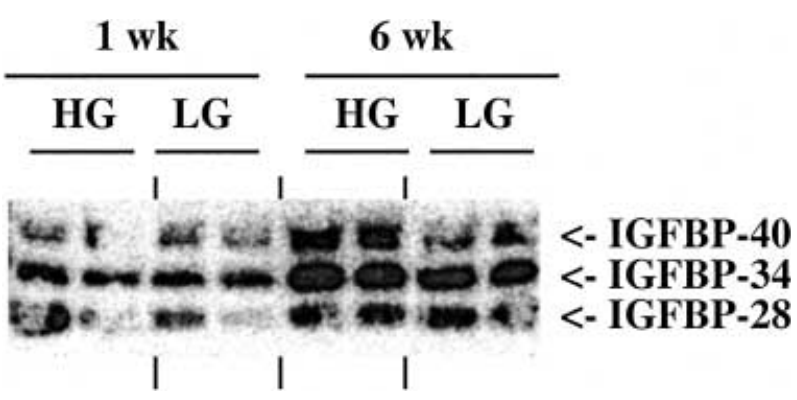

Figure 3 Western ligand blotting (WLB) of sera from 1- and 6-week-old HG and LG chickens. For each lane, $8 \mu \mathrm{l}$ of a serum from individual HG and LG chickens were submitted to WLB using ${ }^{125}$ I-hIGF-I ligand. re-fed states, where circulating insulin levels were significantly higher in HG than LG chickens (LSM comparisons, 4 h re-feeding: $P<0 \cdot 001,24$ h re-feeding: $P<0 \cdot 05)$.

Circulating IGF-I and IGF-II concentrations (Fig. 4) were altered $(P<0 \cdot 001)$ by nutritional state and genotype. A significant interaction between the two factors was, however, observed for the two IGFs $(P<0.05$ for IGF-I and $P<0.001$ for IGF-II). For IGF-I, the interaction disappeared if fasting and re-feeding conditions were considered separately; for IGF-II, the interaction was still apparent when fasting alone was considered. Circulating levels of the two IGFs were significantly lower in fasted $(16 \mathrm{~h}$ and $48 \mathrm{~h})$ than in fed animals in both lines (LSM comparisons, $P<0 \cdot 01)$. The amplitude of the fastinginduced decrease of IGF-I was the greatest at $48 \mathrm{~h}$ fasting in the two genotypes, while for IGF-II it was the greatest at $16 \mathrm{~h}$ in LG chickens and at $48 \mathrm{~h}$ in HG chickens. Re-feeding ( $4 \mathrm{~h}$ and $24 \mathrm{~h}$ ) after the $48 \mathrm{~h}$ fast had no significant effect on IGF-I concentrations as compared with those observed in $48 \mathrm{~h}$-fasted chickens. Conversely, after $24 \mathrm{~h}$ of re-feeding, IGF-II levels were restored to the levels observed in fed animals in both genotypes, this recovery started at $4 \mathrm{~h}$ in $\mathrm{HG}$ chickens. Circulating IGF-I concentrations were always significantly higher in HG than in LG chickens, whatever the nutritional state $(P<0.01$ or higher). As a whole, IGF-II levels were also higher $(P<0 \cdot 001)$ in HG than in LG chickens, although mainly in the $16 \mathrm{~h}$-fasted $(P<0 \cdot 001)$ and $4 \mathrm{~h}$ re-fed $(P<0 \cdot 05)$ states. 

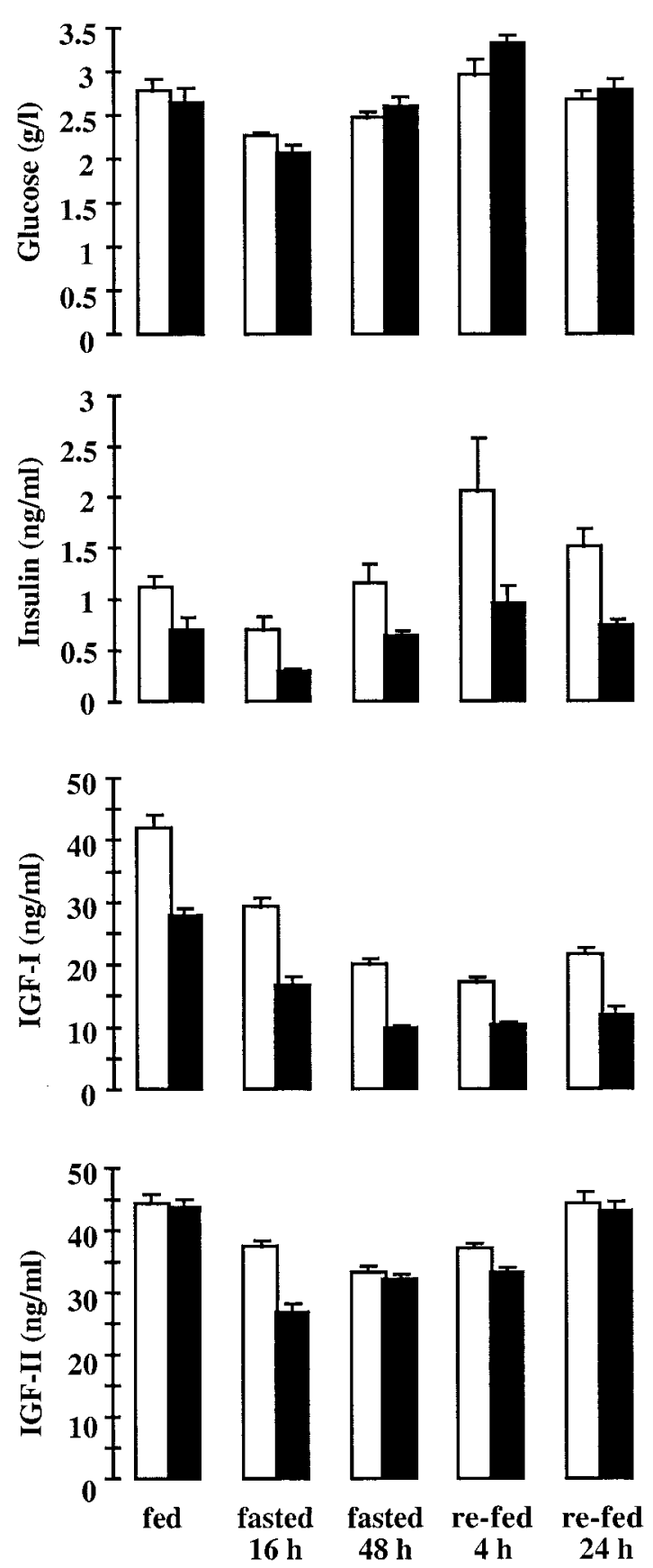

Figure 4 Effect of nutritional state and genotype on circulating levels of glucose, insulin, IGF-I and IGF-II. Individual plasma samples ( $n=7$ in each category) were obtained from 6-week-old HG (open bars) and LG (closed bars) chickens in the fed, fasted ( $16 \mathrm{~h}$ or $48 \mathrm{~h}$ ) or re-fed state ( 4 or $24 \mathrm{~h}$ following the $48 \mathrm{~h}$ fasting). Values are means \pm S.E.M.S. The statistical analysis of these data is presented in the Results section.

The data on circulating IGFBPs are reported in Table 1. IGFBP-28 labelling was significantly altered by fasting $(P<0 \cdot 02)$ in both genotypes, exhibiting a transient increase at $16 \mathrm{~h}$-fasting followed by a return to the fed level after $48 \mathrm{~h}$. Labelling of IGFBP-28 was significantly altered by re-feeding $(P<0.001)$ but only in HG chickens, with a significant decrease at both 4 and $24 \mathrm{~h}$ re-feeding (compared with $48 \mathrm{~h}$ fasting). Variations of IGFBP-34 and -40 labelling were less consistent, except for a large decrease of IGFBP-34 observed upon re-feeding, in the HG chickens. In subsequent experiments, the effect of genotype was examined within each nutritional state: the intensity of IGFBP-28 labelling was higher in HG than in LG chickens (a $72 \%$ increase, $P<0.05$ ) in the 48 h-fasted state. The labelling of IGFBP-34 was also significantly higher in HG chickens, in fed $(+48 \%)$ and 48 h-fasted $(+36 \%)$ states (both $P<0 \cdot 05)$, consistent with the data obtained in the longitudinal study.

\section{Steady state levels of hepatic IGF-I and IGF-II $m R N A$}

Total RNA was extracted from HG and LG chicken livers of the different experimental conditions ( $n=6$ per group). For illustration, the result of a solution hybridization/RPA experiment performed with samples from 1- and 6-weekold chickens using the four different antisense riboprobes (IGF-I, IGF-II, IGFR and 18S) is presented in Fig. 5. By reference to the RNA markers, the protected fragments were of the expected sizes: $226 \mathrm{bp}$ for IGF-I and $274 \mathrm{bp}$ for IGF receptor mRNAs, as previously described (Armstrong and Hogg 1996) and 406 bp for IGF-II and $170 \mathrm{bp}$ for $\mathrm{c} 18 \mathrm{~S}$, as expected from the riboprobes. The figure suggests that IGF-I and IGF-II mRNAs increased with age. Quantitative results expressed as ratios over $18 \mathrm{~S}$ RNA levels (in arbitrary units) are shown in Table 2 for IGF-I and IGF-II mRNA. Although IGFR mRNA were detected in all samples, variations were less consistent and are therefore not reported. IGF-I mRNA levels clearly increased $(P<0 \cdot 001)$ between 1 and 6 weeks of age in both genotypes, and also tended to be higher in the HG line, but not significantly $(P=0.12)$ different. IGF-II mRNA levels were also significantly altered by age $(P<0 \cdot 001)$, but not by genotype $(P=0 \cdot 08)$, exhibiting a significant interaction between age and genotype. Indeed, when each factor was analysed separately, IGF-II mRNA levels increased significantly with age in the HG genotype only $(P<0 \cdot 01)$, leading to significantly higher levels in HG than in LG chickens at 6 weeks of age $(P<0 \cdot 05)$.

The effect of nutritional status on hepatic mRNA levels in 6-week-old HG and LG chickens of the 38th generation is summarized in Fig. 6A (effect of fasting) and 6B (effect of re-feeding). IGF-I mRNA levels were significantly $(P<0 \cdot 001)$ altered by fasting. They were already decreased at $16 \mathrm{~h}$ of fasting and remained low at $48 \mathrm{~h}$ in both lines (LSM comparisons, $P<0 \cdot 01$ ). Re-feeding (Fig. $6 \mathrm{~B})$ tended to increase IGF-I mRNA $(P=0 \cdot 10)$, at least in the HG genotype. IGF-II mRNA was not significantly altered by fasting or re-feeding, although a trend for a decrease was noticed during fasting $(P=0 \cdot 06)$. A 
Table 1 Effect of nutritional state on plasma IGFBPs

\begin{tabular}{|c|c|c|c|c|c|}
\hline Genotype & Experiment & Nutritional state & $\begin{array}{l}\text { IGFBP-28 } \\
(\mathrm{aU})\end{array}$ & $\begin{array}{l}\text { IGFBP-34 } \\
(\mathrm{aU})\end{array}$ & $\begin{array}{l}\text { IGFBP-40 } \\
(\mathrm{aU})\end{array}$ \\
\hline $\mathrm{HG}$ & Fasting & $\begin{array}{l}\text { Fed } \\
\text { Fasted (16 h) } \\
\text { Fasted (48 h) } \\
\text { ANOVA }\end{array}$ & $\begin{array}{l}0 \cdot 9 \pm 0 \cdot 2^{\mathrm{a}} \\
1 \cdot 8 \pm 0 \cdot 2^{\mathrm{b}} \\
1 \cdot 1 \pm 0 \cdot 2^{\mathrm{a}} \\
P<0 \cdot 05\end{array}$ & $\begin{array}{l}2 \cdot 6 \pm 0 \cdot 2 \\
3 \cdot 1 \pm 0 \cdot 4 \\
2 \cdot 6 \pm 0 \cdot 2 \\
\mathrm{NS}\end{array}$ & $\begin{array}{l}1 \cdot 3 \pm 0 \cdot 2 \\
2 \cdot 0 \pm 0 \cdot 2 \\
1 \cdot 3 \pm 0 \cdot 3 \\
\text { NS }\end{array}$ \\
\hline HG & Re-feeding & $\begin{array}{l}\text { Fasted (48 h) } \\
\text { Re-fed ( } 4 \text { h) } \\
\text { Re-fed }(24 \text { h) } \\
\text { ANOVA }\end{array}$ & $\begin{array}{l}2 \cdot 4 \pm 0 \cdot 5^{a} \\
0 \cdot 5 \pm 0 \cdot 1^{b} \\
0 \cdot 7 \pm 0 \cdot 2^{b} \\
P<0 \cdot 001\end{array}$ & $\begin{array}{l}4 \cdot 6 \pm 0 \cdot 5^{a} \\
2 \cdot 0 \pm 0 \cdot 4^{b} \\
1 \cdot 8 \pm 0 \cdot 2^{b} \\
P<0 \cdot 001\end{array}$ & $\begin{array}{l}0 \cdot 9 \pm 0 \cdot 1 \\
1 \cdot 2 \pm 0 \cdot 1 \\
1 \cdot 4 \pm 0 \cdot 3 \\
\text { NS }\end{array}$ \\
\hline LG & Fasting & $\begin{array}{l}\text { Fed } \\
\text { Fasted (16 h) } \\
\text { Fasted (48 h) } \\
\text { ANOVA }\end{array}$ & $\begin{array}{l}0 \cdot 9 \pm 0 \cdot 2^{\mathrm{a}} \\
3 \cdot 3 \pm 0 \cdot 8^{\mathrm{b}} \\
0 \cdot 5 \pm 0 \cdot 1^{\mathrm{a}} \\
P<0 \cdot 001\end{array}$ & $\begin{array}{l}3 \cdot 8 \pm 0 \cdot 5 \\
2 \cdot 9 \pm 0 \cdot 5 \\
2 \cdot 4 \pm 0 \cdot 2 \\
\text { NS }\end{array}$ & $\begin{array}{l}1 \cdot 6 \pm 0 \cdot 2^{\mathrm{a}} \\
1 \cdot 6 \pm 0 \cdot 4^{\mathrm{a}} \\
0 \cdot 7 \pm 0 \cdot 1^{\mathrm{b}} \\
P<0 \cdot 05\end{array}$ \\
\hline LG & Re-feeding & $\begin{array}{l}\text { Fasted (48 h) } \\
\text { Re-fed }(4 \mathrm{~h}) \\
\text { Re-fed }(24 \mathrm{~h}) \\
\text { ANOVA }\end{array}$ & $\begin{array}{l}0 \cdot 8 \pm 0 \cdot 1 \\
0 \cdot 9 \pm 0 \cdot 1 \\
0 \cdot 9 \pm 0 \cdot 3 \\
\text { NS }\end{array}$ & $\begin{array}{l}2 \cdot 7 \pm 0 \cdot 2 \\
3 \cdot 3 \pm 0 \cdot 3 \\
3 \cdot 3 \pm 0 \cdot 4 \\
\text { NS }\end{array}$ & $\begin{array}{l}1 \cdot 3 \pm 0 \cdot 3 \\
1 \cdot 6 \pm 0 \cdot 2 \\
1 \cdot 7 \pm 0 \cdot 3 \\
\text { NS }\end{array}$ \\
\hline
\end{tabular}

\footnotetext{
For each genotype, the effect of fasting (fed vs fasted 16 or $48 \mathrm{~h}$ ) or the effect of re-feeding (fasted $48 \mathrm{~h}$ vs re-fed 4 or $24 \mathrm{~h}$ following $48 \mathrm{~h}$ fasting) were tested independently. Individual plasma samples ( $n=6$ in each category) were submitted to Western ligand blotting using ${ }^{125}$ I-hIGF-I. The radioactivity in each band was quantitated using a Phosphorimager and expressed as arbitrary units (aU). Values are means \pm S.E.M.S and were analysed by one-way ANOVA and subsequent least square means comparisons were performed between groups for each IGFBP moiety. Different superscripts indicate a significant difference between two means at the $P<0.05$ or higher level, NS=non significant.
}

significant difference between genotypes was observed for both the IGF-I and IGF-II transcripts during the fasting and the re-feeding period $(P<0 \cdot 001$ in each case). IGF-I
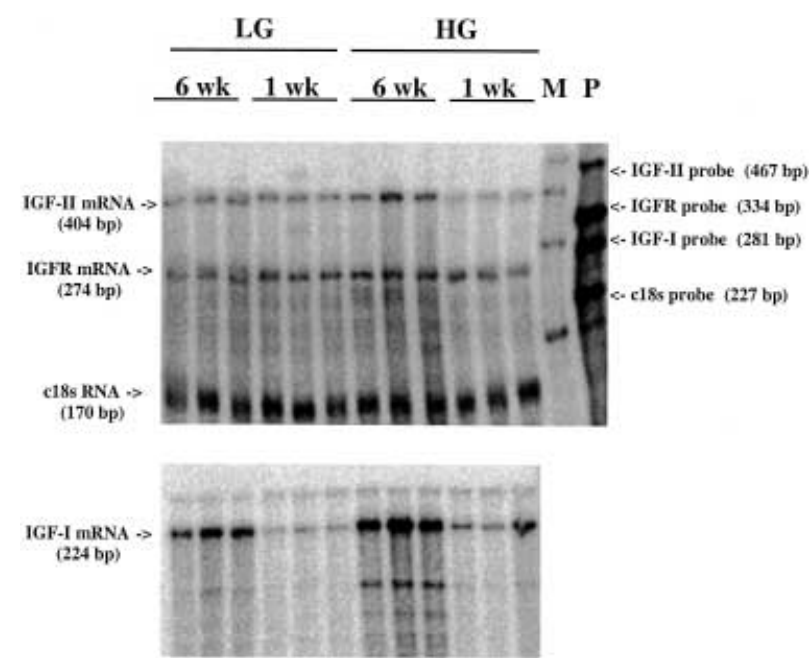

Figure 5 Hepatic IGF-I, IGF-II, IGF-1R and c18S RNA expression in 1 - and 6-week-old HG and LG chickens. In each lane, $20 \mu \mathrm{g}$ of a liver RNA from individual HG and LG chickens aged 1 or 6 weeks $(n=3)$ were submitted to solution hybridization/RPA using antisense RNA probes as described in Materials and Methods. The two extreme right lanes contain unhybridized probes $(\mathrm{P})$ and RNA size markers ( $M$, from top to bottom of the picture: 500, 400, $300,200 \mathrm{bp})$. The quantitative results of six chickens per category are presented in Table 2.
mRNA levels were significantly higher in HG chickens than in LG chickens in each nutritional condition (LSM comparisons, $P<0 \cdot 05$ ). As a whole, the levels of the IGF-II transcripts were also higher in the HG chickens than in LG chickens across the fasting and re-feeding experiments.

\section{Discussion}

The objective of the present study was to compare the components of the IGF system between two genotypes of chickens divergently selected for high (HG) or low (LG) growth rate. This has been done with two generations, at different ages and in different nutritional states.

Circulating IGF-I concentrations markedly increased with age, until chickens of both genotypes reached a body weight of about $1 \mathrm{~kg}$ (6 weeks in HG and 12 weeks in LG). This is consistent with a number of previous reports, in which a decline was observed following a plateau in older (or heavier) birds (Johnson et al. 1990, McGuinness \& Cogburn 1990, McMurtry et al. 1994, Radecki et al. 1997). Circulating IGF-II levels also increased with age (1 week vs 6 weeks of age) although with less contrast. In the chicken, previous data vary from the absence of post-hatch variations (Radecki et al. 1997) to a fall from hatch up to at least 50 days of age (McMurtry et al. 1998). In mammalian species, during the postnatal period, results differ widely between species with almost undetectable 
Table 2 Effect of age and genotype on hepatic expression of IGF-I, IGF-II and IGF-1R mRNAs

\begin{tabular}{|c|c|c|c|}
\hline Genotype & $\begin{array}{l}\text { Age } \\
\text { (weeks) }\end{array}$ & $\begin{array}{l}\text { IGF-I mRNA } \\
(\mathrm{aU})\end{array}$ & $\begin{array}{l}\text { IGF-II mRNA } \\
(\mathrm{aU})\end{array}$ \\
\hline HG & $\begin{array}{l}1 \\
6\end{array}$ & $\begin{array}{l}53 \cdot 0 \pm 13 \cdot 6^{\mathrm{a}} \\
246 \cdot 2 \pm 34 \cdot 4^{\mathrm{b}}\end{array}$ & $\begin{array}{l}8 \cdot 5 \pm 0 \cdot 9^{a} \\
23 \cdot 1 \pm 3 \cdot 9^{b}\end{array}$ \\
\hline LG & $\begin{array}{l}1 \\
6\end{array}$ & $\begin{array}{l}32 \cdot 2 \pm 6 \cdot 8^{\mathrm{a}} \\
189 \cdot 4 \pm 30 \cdot 7^{\mathrm{b}}\end{array}$ & $\begin{array}{l}10 \cdot 8 \pm 0 \cdot 8^{a} \\
13 \cdot 0 \pm 1 \cdot 1^{a}\end{array}$ \\
\hline $\begin{array}{l}\text { Statistics } \\
\text { (two-way ANOVA) }\end{array}$ & $\begin{array}{l}\text { Line } \\
\text { Age } \\
\text { Interaction }\end{array}$ & $\begin{array}{l}\text { NS } \\
* * \\
\text { NS }\end{array}$ & $\begin{array}{l}\text { NS } \\
* * \\
* *\end{array}$ \\
\hline
\end{tabular}

Total hepatic RNA ( $n=6$ in each category) was obtained from HG and LG chickens of the 37 th generation at 1 or 6 weeks of age. IGF-I and IGF-II mRNA levels were detected by solution hybridization/RNase protection assay and the radioactivity in each band was quantitated using a Phosphorimager and expressed in arbitrary units (aU) as a ratio of the band corresponding to $\mathrm{c} 18 \mathrm{~S}$ rRNA. The data (mean \pm S.E.M.) were analysed by two-way ANOVA (NS= non significant, ${ }^{*} P<0 \cdot 05$; ${ }^{*} * P<0 \cdot 01$ ). Least square means comparisons were subsequently performed between groups within a column. Significant differences between two means at the $P<0.05$ level or higher are indicated by different superscripts.

circulating IGF-II in rodents (Moses et al. 1980, Daughaday et al. 1982) or increasing IGF-II levels in the pig (Lee et al. 1993). The large increase in circulating IGF-I concentrations observed in both genotypes between 1 and 6 weeks was accompanied by a marked increase in

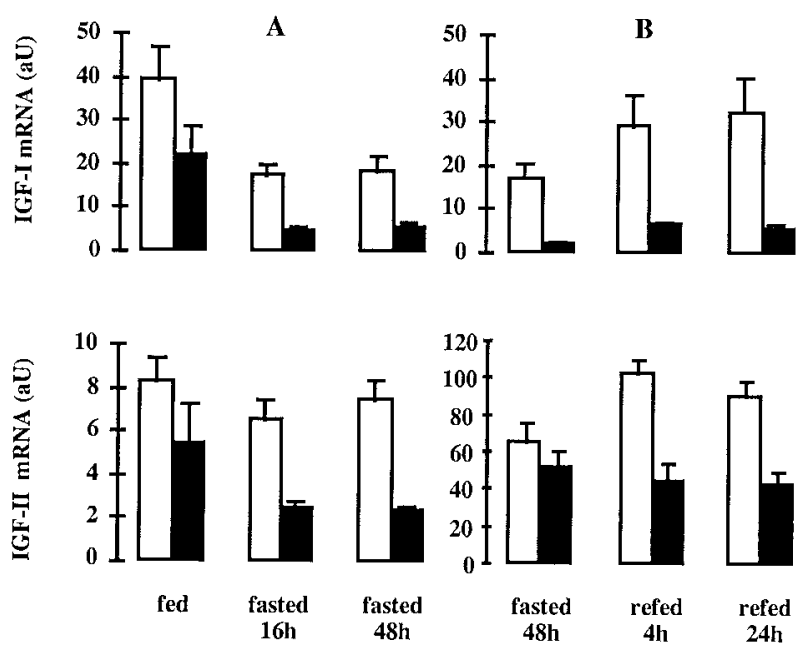

Figure 6 Effect of nutritional state and genotype on the expression of hepatic IGF-I and IGF-II RNA. The effect of fasting (A: fed vs fasted 16 or $48 \mathrm{~h}$ ) and re-feeding (B: fasted 48 vs re-fed $4 \mathrm{~h}$ or $24 \mathrm{~h}$ following the $48 \mathrm{~h}$ fasting) were tested in independent experiments. RNA extracts were obtained from 6-week-old HG (open bars) and LG (closed bars) chickens ( $n=6$ in each category) and were submitted to solution hybridization/RPA. The radioactivity in each band was quantitated using a Phosphorimager. The expression of each specific mRNA was calculated as a ratio of the radioactivity in the c18S protected fragment with results expressed as arbitrary units (aU). Values are means \pm S.E.M.S. The statistical analysis of these data is presented in the Results section. hepatic IGF-I mRNA levels (about fivefold), consistent with previous observations in the chicken (Kajimoto \& Rotwein 1989, Kikuchi et al. 1991, Burnside \& Cogburn 1992). To our knowledge, the present study is the first one to consider possible developmental changes in IGF-II mRNA levels in the chicken, showing an increase between 1 and 6 weeks of age, at least in HG chickens.

At 6 weeks of age, circulating concentrations of IGF-I and IGF-II fell during the $48 \mathrm{~h}$ fast as previously observed in another genotype (Beccavin et al. 1999). In the present study, this decrease was largely engaged at $16 \mathrm{~h}$ of fasting for both peptides and in both genotypes. Following re-feeding (4 or $24 \mathrm{~h}$ following a $48 \mathrm{~h}$ fasting period) circulating levels of IGF-II returned to levels found in the fed state, whereas IGF-I remained low. It has previously been observed that 4 days of food restriction $(50 \%$ of ad libitum intake) in 3-week-old broiler chickens lowered circulating IGF-I and hepatic IGF-I mRNA levels and that 3 days of ad libitum intake returned it to normal (Kita et al. 1996), but these variations were not unambiguously associated with specific changes in liver IGF-I mRNA (Kita et al. 1996, 1998). Presently, liver IGF-I mRNA levels in both HG and LG genotypes (expressed as a ratio of c18S rRNA) were greatly decreased by fasting, as early as $16 \mathrm{~h}$, most likely accounting for the gradual decrease in circulating IGF-I levels. Liver IGF-I mRNA was not restored by re-feeding up to $24 \mathrm{~h}$ (only a small but not significant increase was suggested) which would account for the lack of increase in IGF-I levels after $24 \mathrm{~h}$ re-feeding. This slow rate of recovery for liver IGF-I mRNA is in agreement with observations in the rat where, after 3 days of fasting, IGF-I levels remain suppressed for at least the first $24 \mathrm{~h}$ after re-feeding (Frystyk et al. 1999 and references herein). Circulating IGF-II levels exhibited a rapid decrease during fasting with a 
return initiated at $4 \mathrm{~h}$ and completed with $24 \mathrm{~h}$ of re-feeding. Surprisingly, this pattern was observed with a non-significant decrease of hepatic IGF-II mRNA. In the chicken, a distinct regulation is therefore suggested for the two IGFs in liver. The most important and new observation concerns the effect of genotype on circulating IGFs and steady state hepatic mRNA levels. IGF-I exhibited significantly higher circulating concentrations in $\mathrm{HG}$ chickens across ages between 1 and 6 weeks in two generations. At the 38th generation, this difference was significant at each age and in each nutritional state at 6 weeks of age. Steady state IGF-I mRNA levels measured at 6 weeks of age were also significantly higher in the liver of $\mathrm{HG}$ chickens $(+100 \%$ or more) in each nutritional state. Similar trends were also observed at 1 and 6 weeks of age in the first measurement ( $+60 \%$ and $+30 \%$ respectively), which lead us to favour the hypothesis that differences in steady state IGF-I mRNA levels contribute to differences in circulating IGF-I levels at least around 6 weeks of age. In the HG chickens, circulating IGF-II and hepatic mRNA levels tended to be higher than in LG chickens, reproducing the feature observed with IGF-I, although at a lower extent and dependent upon age and nutritional state.

The present study also provided new information concerning circulating IGFBPs. All three IGFBPs (28, 34 and $40 \mathrm{kDa}$ ) increased with age, as previously observed in layer chickens (Radecki et al. 1997) and consistent with the idea that IGFs circulate as complexes with IGFBPs. The chicken IGFBP-40 corresponds to IGFBP-3 in mammalian species, while IGFBP-34 corresponds to IGFBP-2. The later was higher in HG chickens, consistent with the hypothesis that this could be the main IGF carrier in the chicken (see Duclos et al. 1999 and McMurtry et al. 1997). The chicken IGFBP-28 was presently shown to depend upon the nutritional state in both genotypes. Its radiolabelling increased with $16 \mathrm{~h}$ of fasting and surprisingly returned to fed levels by $48 \mathrm{~h}$ of fasting, while in a previous study (Beccavin et al. 1999) using older (9-weekold) and heavier $(2.4 \mathrm{~kg})$ chickens from the fat or lean genotypes, it was still higher at $48 \mathrm{~h}$ of fasting than in the fed state. IGFBP-28 was higher in HG than in LG chickens at $48 \mathrm{~h}$ of fasting. Re-feeding decreased its level in the former not the latter genotype. Similarly, IGFBP-34 levels dropped dramatically upon re-feeding only in HG chickens. This suggests that metabolic regulation depends upon age, body weight and/or genotype. From its size and its sensitivity to the nutritional state, it is very likely that chicken IGFBP-28 is the equivalent of IGFBP-1 in mammals, which is very sensitive to metabolic regulation and is mainly under dual control of glucose and insulin (see Thissen et al. 1994, for review). Presently, both plasma glucose and insulin in the two genotypes decreased at $16 \mathrm{~h}$ fasting which would account, at least in part, for the simultaneous and large increase in circulating IGFBP-28. At $48 \mathrm{~h}$ fasting, glucose, insulin and IGFBP-28 resumed fed levels in the chicken, unlike in rats where glucose and insulin remained low and IGFBP-1 high (Frystyk et al. 1999). Consistent with the previous observations, IGFBP-28 decreased during re-feeding in the HG genotype while insulin significantly increased.

As a whole, HG and LG chickens clearly differ in circulating IGF-I concentrations and liver IGF-I mRNA, exhibiting high or low levels respectively. Similar, although less clear-cut, differences were observed for IGF-II concentrations and liver IGF-II mRNA levels. While a direct relationship between growth rate and IGF-I or IGF-II is clearly demonstrated in transgenic mice (total knock-out or over-expression experiments; see Efstratiadis 1998 for review), such observations are not so numerous in 'natural' models. Circulating IGF-I levels (but not IGF-II) also differed at 7 weeks of age (Scanes et al. 1989) in a comparable model of divergently selected broilers with high or low growth rate (Scanes et al. 1989). By contrast, no significant difference in circulating IGF-I levels could be observed from 1 to 10 weeks of age between three unrelated genotypes of chickens exhibiting different growth rates (in a layer line with low body weight and in two broiler lines with high or very high body weight) (Goddard et al. 1988) which is somewhat surprising. In mice divergently selected for high or low body weight (Hoeflich et al. 1998), higher circulating levels of IGF-I were observed in control or heavy animals compared with the smaller animals, together with higher levels of circulating insulin, as observed in the present study. In mice carrying the high growth (hg) gene (Medrano et al. 1991), higher IGF-I concentrations were also observed. Mice selected for high or low circulating IGF-I levels exhibited high or low growth rates as correlated responses (Baker et al. 1991). However, if body weight is the objective, direct selection on this character is more efficient than an indirect one on IGF-I levels (Baker et al. 1991). Altogether, the present data and most of the literature (Efstratiadis 1998) suggest a direct and causal relationship between circulating IGF-I levels and body growth rates. However, this hypothesis has been recently challenged in mice where specific and complete disruption of the liver IGF-I gene has been achieved in the post-natal period: circulating IGF-I levels were decreased by $75 \%$ while normal growth rate was maintained (Sjogren et al. 1999, Yakar et al. 1999). In these conditions, the liver appears to be the main source of circulating IGF-I whereas tissue growth would rely mostly, if not exclusively, on autocrine/paracrine mechanisms, without the need for a clear increase in the expression of IGF-I in peripheral tissues. In order to fully validate this hypothesis, potential compensatory mechanisms such as up-regulation of IGF-II peptide or IGF type-1 receptor synthesis and/or down-regulation of IGFBPs (although only IGFBP-3 has been investigated and found to be decreased) have to be ruled out. One can also speculate that in the post-natal period, 'normal' growth could be possible in the presence of minimal levels 
of circulating IGF-I, whereas 'enhanced' growth would require higher than normal IGF-I levels, most likely provided by the liver in normal physiological conditions.

In conclusion, the high and low growth rates of divergently selected chickens were respectively associated with high and low levels of hepatic IGF-I mRNA and circulating IGF-I levels during the early post-hatching period. Correlated changes in circulating IGF-II, although of smaller magnitude, would also contribute to the divergence of growth rates between these two genotypes.

\section{Acknowledgements}

We thank Drs Märki and Kaufman (Ciba-Geigy, Basle, Switzerland) for the gift of recombinant human IGF-I and -II, Prof. Nishikawa (Ishikawa, Japan) for the gift of the IGF-II antibody, Dr E LeBihan-Duval and N Millet of Station de Recherches Avicoles for the genetic selection and the Unité Expérimentale Avicole for careful breeding of the experimental lines of chickens. This study was supported by INRA and by a grant from Association Française contre les Myopathies (AFM) to J S and M J D.

\section{References}

Armstrong DG \& Hogg CO 1992 The expression of a putative insulin-like growth factor-I receptor gene in the liver of the developing chick. Journal of Molecular Endocrinology 8 193-201.

Armstrong DG \& Hogg CO 1996 Insulin-like growth factor I (IGF-I), IGF-II and type-I IGF receptor gene expression in the ovary of the laying hen. Journal of Reproduction and Fertility 106 101-106.

Baker RL, Peterson AJ, Bass JJ, Amyes NC, Breier BH \& Gluckman PD 1991 Replicated selection for insulin-like growth factor-1 and body weight in mice. Theoretical and Applied Genetics 81 685-692.

Beccavin C, Chevalier B, Simon J \& Duclos MJ 1999 Circulating insulin-like growth factors (IGF-I and -II) and IGF binding proteins in divergently selected fat or lean chickens: effect of prolonged fasting. Growth Hormone and IGF Research 9 187-194.

Burke WH \& Marks HL 1982 Growth hormone and prolactin levels in non selected and selected broiler lines of chickens from hatch to eight weeks of age. Growth 46 283-295.

Burnside J \& Cogburn LA 1992 Developmental expression of hepatic growth hormone receptor and insulin-like growth factor-I mRNA in the chicken. Molecular and Cellular Endocrinology 89 91-96.

Chomczynski P \& Sacchi N 1987 Single-step method of RNA isolation by acid guanidinium thiocyanate-phenol-chloroform extraction. Analytical Biochemistry 162 156-159.

Darling DC \& Brickell PM 1996 Nucleotide sequence and genomic structure of the chicken insulin-like growth factor-II (IGF-II) coding region. General and Comparative Endocrinology 102 283-287.

Daughaday WH \& Rotwein P 1989 Insulin-like growth factors I and II. Peptide, messenger ribonucleic acid and gene structures, serum, and tissue concentrations. Endocrine Reviews 10 68-91.

Daughaday WH, Parker KA, Borowsky S, Trivedi B \& Kapadia M 1982 Measurement of somatomedin-related peptides in fetal, neonatal, and maternal rat serum by insulin-like growth factor (IGF) I radioimmunoassay, IGF-II radioreceptor assay (RRA), and multiplication-stimulating activity RRA after acid-ethanol extraction. Endocrinology 110 575-581.
Duclos MJ, Chevalier B \& Simon J 1994 Preferential binding of insulin-like growth factors to a binding protein rather than to receptors on chicken hepatoma cell (LMH) membranes. Growth Regulation 4 155-163.

Duclos MJ, Chevalier B, Rémignon H, Ricard FH, Goddard C \& Simon J 1996 Divergent selection for high or low growth rate modifies the response of muscle cells to serum or insulin-like growth factor-I in vitro. Growth Regulation 6 176-184.

Duclos MJ, Beccavin C \& Simon J 1999 Genetic models for the study of insulin-like growth factors (IGF) and muscle development in birds compared with mammals. Domestic Animal Endocrinology 17 231-243.

Efstratiadis A 1998 Genetics of mouse growth. International Journal of Developmental Biology 42 955-976.

Frystyk J, Delhanty PJ, Skjaerbaek C \& Baxter RC 1999 Changes in the circulating IGF system during short-term fasting and refeeding in rats. American Journal of Physiology 277 E245-E252.

Goddard C, Wilkie RS \& Dunn IC 1988 The relationship between insulin-like growth factor-1, growth hormone, thyroid hormones and insulin in chickens selected for growth. Domestic Animal Endocrinology 5 165-176.

Harvey S, Scanes CG, Chadwick A \& Bolton NJ 1979 Growth hormone and prolactin secretion in growing domestic fowl: influence of sex and breed. British Poultry Science 20 9-17.

Hoeflich A, Schmidt P, Föll J, Rottman O, Weber MM, Kolb HJ, Pirchner F \& Wolf E 1998 Altered growth of mice divergently selected for body weight is associated with complex changes in the growth hormone/insulin-like growth factor system. Growth Hormone and IGF Research 8 113-123.

Johnson AL, Bridgham JT, Digby MR \& Lowenthal JW 1998 Expression of the inhibitor of T-cell apoptosis (ita) gene in hen ovarian follicles during development. Biology of Reproduction $\mathbf{5 8}$ 414-420.

Johnson RJ, McMurtry JP \& Ballard FJ 1990 Ontogeny and secretory patterns of plasma insulin-like growth factor-I concentrations in meat-type chickens. Journal of Endocrinology 124 81-87.

Kajimoto Y \& Rotwein P 1989 Structure and expression of a chicken insulin-like growth factor I precursor. Molecular Endocrinology 3 1907-1913.

Kikuchi K, Buonomo FC, Kajimoto Y \& Rotwein P 1991 Expression of insulin-like growth factor-I during chicken development. Endocrinology 128 1323-1328.

Kita K, Tomas FM, Owens PC, Knowles SE, Forbes BE, Upton Z, Hughes R \& Ballard FJ 1996 Influence of nutrition on hepatic IGF-I mRNA levels and plasma concentrations of IGF-I and IGF-II in meat-type chickens. Journal of Endocrinology 149 181-190.

Kita K, Hangsanet K, Shibata T, Conlon MA, Sasaki T, Saito N \& Okumura J 1998 Refeeding increases hepatic insulin-like growth factor-I (IGF-I) gene expression and plasma IGF-I concentration in fasted chicks. British Poultry Science 39 679-682.

Lee CY, Chung CS \& Simmen FA 1993 Ontogeny of the porcine insulin-like growth factor system. Molecular and Cellular Endocrinology 93 71-80.

McGuinness MC \& Cogburn LA 1990 Measurement of developmental changes in plasma insulin-like growth factor-I levels of broiler chickens by radioreceptor assay and radioimmunoassay. General and Comparative Endocrinology 79 446-458.

McMurtry JP, Francis GL, Upton FZ, Rosselot G \& Brocht DM 1994 Developmental changes in chicken and turkey insulin-like growth factor-I (IGF-I) studied with a homologous radioimmunoassay for chicken IGF-I. Journal of Endocrinology 142 225-234.

McMurtry JP, Francis GL \& Upton Z 1997 Insulin-like growth factors in poultry. Domestic Animal Endocrinology 14 199-229.

McMurtry JP, Rosebrough RW, Brocht DM, Francis GL, Upton Z \& Phelps P 1998 Assessment of developmental changes in chicken and turkey insulin-like growth factor-II by homologous radioimmunoassay. Journal of Endocrinology 157 463-473. 
Medrano JF, Pomp D, Sharrow L, Bradford GE, Downs TR \& Frohman LA 1991 Growth hormone and insulin-like growth factor-I measurements in high growth (hg) mice. Genetic Research 58 67-74.

Moses AC, Nissley SP, Short PA, Rechler MM, White RM, Knight AB \& Higa OZ 1980 Increased levels of multiplication-stimulating activity, an insulin-like growth factor, in rat fetal serum. PNAS $\mathbf{7 7}$ 3649-3653.

Nir I, Harvey S, Cherry JA, Dunnington EA, Klandorf H \& Siegel PB 1987 Growth-associated traits in parental and F1 populations of chickens under different feeding programs. 4. Growth and thyroid hormones. Poultry Science 66 32-37.

Oudin A, Chevalier B, Simon J \& Duclos MJ 1998 Muscle insulin-like growth factor-I (IGF-I) receptors in chickens with high and low body weight: effects of age and muscle fibre type. Growth Hormone and IGF Research 8 243-250.

Radecki SV, Capdevielle MC, Buonomo FC \& Scanes CG 1997 Ontogeny of insulin-like growth factors (IGF-I and IGF-II) and IGF-binding proteins in the chicken following hatching. General and Comparative Endocrinology 107 109-117.

Ricard FH 1975 Essai de sélection sur la forme de la courbe de croissance chez le poulet. Annales de Genetique et Selection Animales 7 $427-443$.

Scanes CG, Dunnington EA, Buonomo FC, Donoghue DJ \& Siegel PB 1989 Plasma concentrations of insulin like growth factors
(IGF-)I and IGF-II in dwarf and normal chickens of high and low weight selected lines. Growth Development and Aging 53 151-157.

Simon J \& Leclercq B 1982 Longitudinal study of adiposity in chickens selected for high or low abdominal fat content: further evidence of a glucose-insulin imbalance in the fat line. Journal of Nutrition 112 1961-1973.

Simon J, Freychet P \& Rosselin G 1974 Chicken insulin: radioimmunological characterization and enhanced activity in rat fat cells and liver plasma membranes. Endocrinology 95 1439-1449.

Sjogren K, Liu JL, Blad K, Skrtic S, Vidal O, Wallenius V, LeRoith D, Tornell J, Isaksson OG, Jansson JO \& Ohlsson C 1999 Liver-derived insulin-like growth factor I (IGF-I) is the principal source of IGF-I in blood but is not required for postnatal body growth in mice. PNAS 96 7088-7092.

Thissen JP, Ketelslegers JM \& Underwood LE 1994 Nutritional regulation of the insulin-like growth factors. Endocrine Reviews $\mathbf{1 5}$ 80-101.

Yakar S, Liu JL, Stannard B, Butler A, Accili D, Sauer B \& LeRoith D 1999 Normal growth and development in the absence of hepatic insulin-like growth factor I. PNAS 96 7324-7329.

Received in final form 9 October 2000

Accepted 20 October 2000 